\title{
PARTITIONING OF BARIUM BETWEEN COEXISTING K-FELDSPARS AND PLAGIOCLASES IN THE BUSHVELD GRANITES FROM THE ZAAIPLAATS AREA, SOUTH AFRICA
}

\author{
JUSSI TUOMAS OLLILA
}

\begin{abstract}
OLLILA, JUSSI TUOMAS, 1984. Partitioning of barium between coexisting Kfeldspars and plagioclases in Bushveld granites from the Zaaiplaats area, South Africa. Bult. Geol. Soc. Finland 56, Part 1-2, 53-57.

The barium contents of the coexisting K-feldspars and plagioclases in the Bushveld granites from the Zaaiplaats tin mine area were determined by electron microprobe analyses. The average weight distribution coefficients of barium for $\mathrm{K}$ feldspar over plagioclase in the Main, Bobbejaankop and Lease granites are 10, 2 and 4, respectively, the barium contents of the $\mathrm{K}$-feldspars being $0.20,0.04$ and 0.08 weight per cent respectively. The data indicate in situ fractional crystallization as a possible model for the origin of the Bobbejaankop granite with its syngenetic tin deposits.
\end{abstract}

Key words: barium analyses, Bushveld granites, K-feldspar, plagioclase, fractional crystallization, tin deposits.

Jussi Tuomas Ollila: Geological Survey of Finland, P.O. Box 77, 96101 Rovaniemi 10, Finland.

\section{Introduction}

Recent geochemical studies on the Bushveld granites in the Zaaiplaats tin mining area, the Central Transvaal, South Africa, have produced evidence in favour of the hypothesis that these rocks crystallized from progressively more hydrous melts and that the ore-forming fluids, derived from the residual fraction of the granite magma intrusion, were concentrated by the mechanism of fractional crystallization (McCarthy and Hasty 1976; McCarthy and Fripp 1980; Lenthall and Hunter 1977).

Barium is captured by the potassium-bearing minerals $\mathrm{K}$-feldspar and biotite, and concentrates in the early fractions during differentiation. The radius of the barium ion is similar to that of the potassium ion, although the barium ion has the same charge as the calcium ion. Because the size effect predominates, barium usually concentrates strongly into $\mathrm{K}$-feldspar with respect to plagioclase (Smith 1974). Geochemical indicators, such as an increase in $\mathrm{K} / \mathrm{Ba}$ or a decrease in $\mathrm{Ba} / \mathrm{Rb}$, are suggestive of differentiation in crystallization of the granitoids.

This paper reports the results of 191 quantitative microprobe analyses of sodium, potassium, calcium and barium on coexisting $\mathrm{K}$-felspars and plagioclases from the stratiform Main granite, and from the tin-bearing Bobbejaankop and Lease granites at the Zaaiplaats tin mine or in its immediate vicinity. The analyses 
were done with an ARL-SEMQ electron microprobe during the author's stay with the Applied Mineralogy Research Group of the Council for Mineral Technology (MINTEK) in Randburg.

\section{Microprobe analyses}

Microprobe analyses for coexisting K-feldspars and plagioclases are summarized in Table 1.
The major elements $\mathrm{Na}, \mathrm{K}$ and $\mathrm{Ca}$ were analysed with $\mathrm{Ba}$ by microprobe and subsequently calculated to orthoclase (Or), albite (Ab), and anorthite (An) on the basis of 24 oxygen. The Or contents of $\mathrm{K}$-feldspars are high in all granite types (in range 91.58 to 98.21 in Main granite, 96.41 to 98.31 in Bobbejaankop granite, and 95.90 to 98.26 in Lease granite) as are the albite contents of plagioclases (range 92.86 to 98.76 in Main granite, 95.07 to 99.16 in Bobbejaankop

Table 1. Mean compositions of coexisting K-feldspars and plagioclases from the Bushveld granites in the Zaaiplaats Area.

\begin{tabular}{|c|c|c|c|c|c|c|c|c|c|c|c|c|c|}
\hline \multirow[t]{2}{*}{ Sample } & \multicolumn{6}{|c|}{ K-feldspar } & \multicolumn{6}{|c|}{ Plagioclase } & \multirow{2}{*}{$\begin{array}{l}\text { Granite } \\
\text { Type }\end{array}$} \\
\hline & $\begin{array}{l}\text { Or } \\
(\%)\end{array}$ & $\begin{array}{c}\mathrm{Ab} \\
(\%)\end{array}$ & $\begin{array}{l}\text { An } \\
(\%)\end{array}$ & $\begin{array}{l}\mathrm{Ba} \\
(\%)\end{array}$ & $\mathrm{K} / \mathrm{Ba}$ & $\begin{array}{l}\text { Number } \\
\text { of Spot } \\
\text { Analyses }\end{array}$ & $\begin{array}{c}\text { Or } \\
(\%)\end{array}$ & $\begin{array}{l}\mathrm{Ab} \\
(\%)\end{array}$ & $\begin{array}{l}\text { An } \\
(\%)\end{array}$ & $\begin{array}{c}\mathrm{Ba} \\
(\%)\end{array}$ & $\mathrm{K} / \mathrm{Ba}$ & $\begin{array}{l}\text { Number } \\
\text { of Spot } \\
\text { Analyses }\end{array}$ & \\
\hline SA 8 & 97.10 & 2.90 & - & 0.26 & 63 & 4 & 1.69 & 97.27 & 0.34 & 0.03 & 9 & 4 & Main Granite \\
\hline SA 14 & - & - & - & $<0.01$ & - & - & 2.63 & 92.86 & 4.51 & 0.02 & 218 & 8 & $-»-$ \\
\hline SA 27 & 96.73 & 3.27 & - & 0.32 & 49 & 2 & 1.61 & 98.41 & 0.10 & 0.02 & 12 & 9 & $-»-$ \\
\hline SA 37 & 98.21 & 1.79 & - & 0.17 & 103 & 2 & 1.11 & 98.59 & 0.21 & 0.02 & 10 & 6 & $-»-$ \\
\hline SA 45 & 97.73 & 2.27 & - & 0.04 & 391 & 4 & 2.64 & 96.57 & 0.49 & 0.03 & 13 & 4 & $-»-$ \\
\hline SA 49 & 94.31 & 5.69 & - & 0.10 & 170 & 4 & 1.97 & 97.74 & 0.29 & 0.03 & 12 & 4 & $-»-$ \\
\hline SA 57 & 98.05 & 1.95 & - & 0.05 & 326 & 3 & 1.71 & 97.98 & 0.31 & 0.03 & 8 & 4 & $-»-$ \\
\hline SA 60 & 98.07 & 1.93 & - & 0.22 & 74 & 5 & 4.84 & 95.70 & 0.28 & 0.03 & 22 & 3 & $-»-$ \\
\hline SA 62 & 98.08 & 1.92 & - & 0.37 & 46 & 2 & 4.73 & 94.90 & 0.34 & $<0.01$ & - & 3 & $-»-$ \\
\hline SA 65 & 98.02 & 1.98 & - & 0.15 & 116 & 7 & 1.24 & 98.76 & - & 0.01 & 12 & 7 & $-»-$ \\
\hline SA 86 & 95.25 & 4.76 & - & 0.22 & 63 & 3 & 2.31 & 97.29 & 0.73 & $<0.01$ & - & 3 & $-»-$ \\
\hline SA 87 & 91.58 & 8.42 & - & 0.12 & 127 & 5 & 3.38 & 95.64 & 0.99 & 0.02 & 23 & 5 & $-»-$ \\
\hline SA 90 & 97.65 & 2.34 & - & 0.45 & 36 & 4 & 2.26 & 97.74 & - & 0.04 & 8 & 5 & $-»-$ \\
\hline SA 95 & 98.05 & 1.95 & - & 0.19 & 91 & 4 & 2.22 & 97.16 & 0.63 & 0.01 & 32 & 5 & $-»-$ \\
\hline $\begin{array}{l}\text { Average } \\
\mathrm{Ba} \text { and } \mathrm{K} / \mathrm{Ba} \\
\text { values }\end{array}$ & & & & 0.20 & 127 & & & & & 0.02 & 16 & & \\
\hline $78-15-2$ & 98.04 & 1.96 & - & 0.011 & 1705 & 4 & 4.03 & 95.07 & 0.90 & 0.02 & 26 & 4 & Bobbejaankop Granite \\
\hline $78-15-4$ & 98.08 & 1.92 & - & 0.04 & 462 & 3 & 2.34 & 97.61 & 0.20 & 0.02 & 17 & 3 & $-»-$ \\
\hline $78-15-8$ & 98.31 & 1.69 & - & 0.05 & 331 & 3 & 0.54 & 99.12 & 0.35 & $<0.01$ & - & 3 & $-»-$ \\
\hline $06377-20$ & 97.70 & 2.30 & - & 0.021 & 1145 & 3 & 2.54 & 97.46 & - & 0.02 & 31 & 3 & - - (Mineralized) \\
\hline $06377-29$ & 97.70 & 2.30 & - & 0.06 & 266 & 4 & 1.82 & 98.18 & - & 0.01 & 22 & 4 & $-»-($ Mineralized $)$ \\
\hline 06377-108 & 97.73 & 2.27 & - & 0.04 & 398 & 4 & 0.84 & 99.16 & - & $<0.01$ & - & 2 & $-»-($ Mineralized $)$ \\
\hline $06377-111$ & 96.41 & 3.59 & - & 0.05 & 292 & 6 & - & - & - & $<0.01$ & - & - & $-»-($ Mineralized) \\
\hline $06377-300$ & 97.96 & 2.03 & - & 0.06 & 285 & 4 & 2.79 & 97.21 & - & 0.02 & 20 & 4 & $-»-$ (Mineralized) \\
\hline $\begin{array}{l}\text { Average } \\
\mathrm{Ba} \text { and } \mathrm{K} / \mathrm{Ba} \\
\text { values }\end{array}$ & & & & 0.04 & 611 & & & & & 0.02 & 23 & & \\
\hline $06377-144$ & 95.90 & 4.10 & - & 0.04 & 388 & 6 & 2.36 & 97.59 & 0.05 & 0.02 & 20 & 6 & Lease Granite \\
\hline $06377-146$ & 98.26 & 1.74 & - & 0.11 & 156 & 3 & 2.59 & 97.41 & 一 & 0.02 & 21 & 3 & $-»-$ \\
\hline $\begin{array}{l}\text { Average } \\
\mathrm{Ba} \text { and } \mathrm{K} / \mathrm{Ba} \\
\text { values }\end{array}$ & & & & 0.08 & 272 & & & & & 0.02 & 20 & & \\
\hline
\end{tabular}


granite, and 97.41 to 97.59 in Lease granite) indicating nearly complete subsolidus exsolution.

The average $\mathrm{Ba}$ value in $\mathrm{K}$-feldspars of the Main granite, $0.20 \%$, is five times higher than that in K-feldspars of the Bobbejaankop granite, $0.04 \%$, whereas the average $\mathrm{Ba}$ content in the Lease granite $\mathrm{K}$-feldspars is $0.08 \%$. The average $\mathrm{Ba}$ content in the plagioclases of all three granite types is $0.02 \%$.

The Ba values of $\mathrm{K}$-feldspars and plagioclases in Table 1 , are the mean values from a number of spot analyses (as shown in Table 1). Samples SA 14, SA 49, SA 86 and SA 90 are from the meso-, or leuco-cratic, coarse-grained variant of the Main granite, with the granularity and texture index of the Waal (1972) being from 8 to 10. The K-feldspars tend to have highly variable mean $\mathrm{Ba}$ contents in these samples. In much the similar way, the mean $\mathrm{Ba}$ contents of the $\mathrm{K}$ feldspars in the porphyritic granophyre and porphyry variants of the Main granite have very pronounced deviations from the average $\mathrm{Ba}$ value. $\mathrm{Ba}$ analyses by electron microprobe have generally been found to be in good agreement with chemical analyses (Smith 1974).

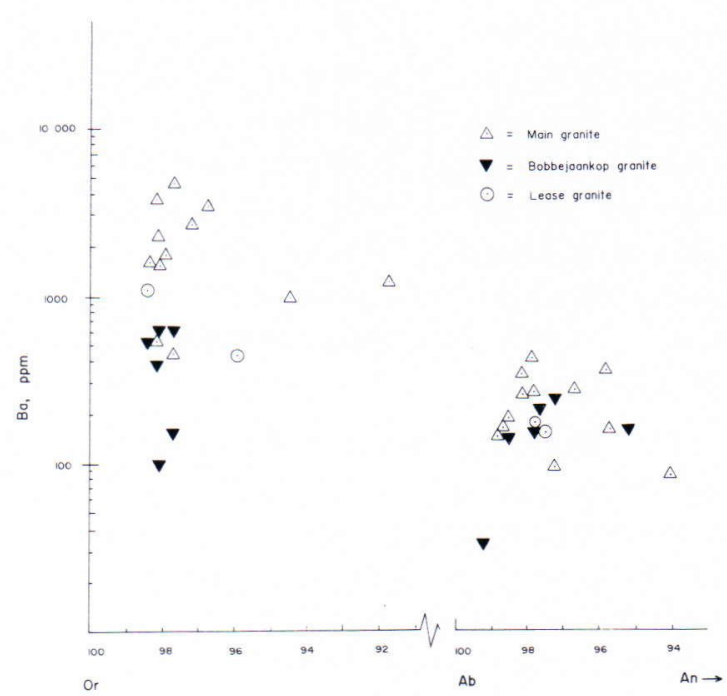

Fig. 1. Distribution of mean Ba contents between the coexisting K-feldspars and plagioclases in the Main, Bobbejaankop and Lease granite samples.
The distribution of the mean $\mathrm{Ba}$ contents between the coexisting $\mathrm{K}$-feldspars and plagioclases of the specimens analysed is shown in Fig. 1, whereas Fig. 2 depicts the mean $\mathrm{K} / \mathrm{Ba}$ ratios. The average $\mathrm{K} / \mathrm{Ba}$ ratio in the Bobbejaankop granite K-feldspars (611) is nearly five times higher than that in the Main granite (127). The average $\mathrm{K} / \mathrm{Ba}$ ratio in the Lease granite $\mathrm{K}$-feldspars is 272 (Table 1).

The average weight distribution coefficients of $\mathrm{Ba}$ for $\mathrm{K}$-feldspar over plagioclase in the Main, Bobbejaankop and Lease granites are 10, 2 and 4, respectively. Fig. 3 depicts the distribution of the mean $\mathrm{Ba}$ values between the coexisting feldspars in the three granite types. In particular, the Main granite samples display highly variable weight distribution coefficients of $\mathrm{Ba}$.

\section{Discussion}

According to the whole rock analyses, both the Bobbejaankop and Lease granites are depleted in $\mathrm{Ba}$ and $\mathrm{Sr}$ and enriched in $\mathrm{Rb}$ relative to the Main granite. The uppermost portions of

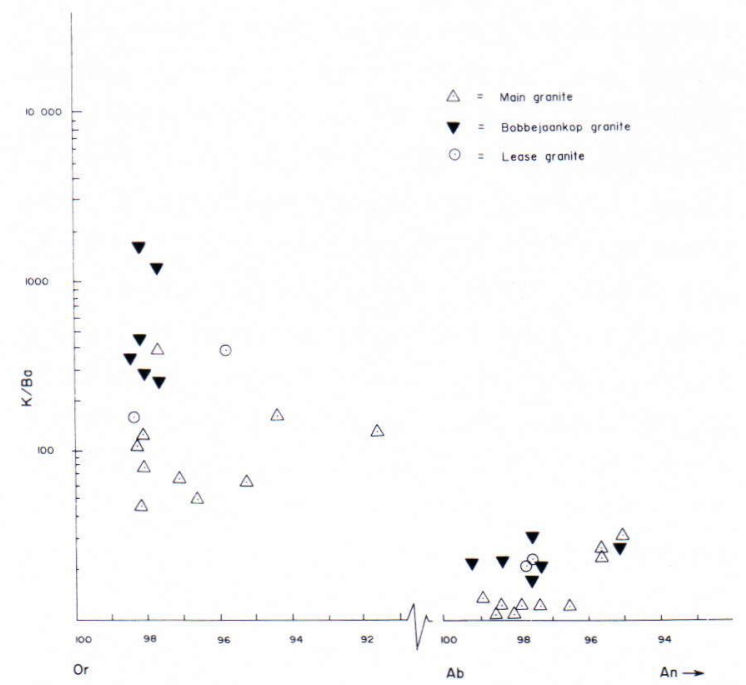

Fig. 2. Distribution of mean $\mathrm{K} / \mathrm{Ba}$ ratios between the coexisting $\mathrm{K}$-feldspars and plagioclases in the Main, Bobbejaankop and Lease granites. 


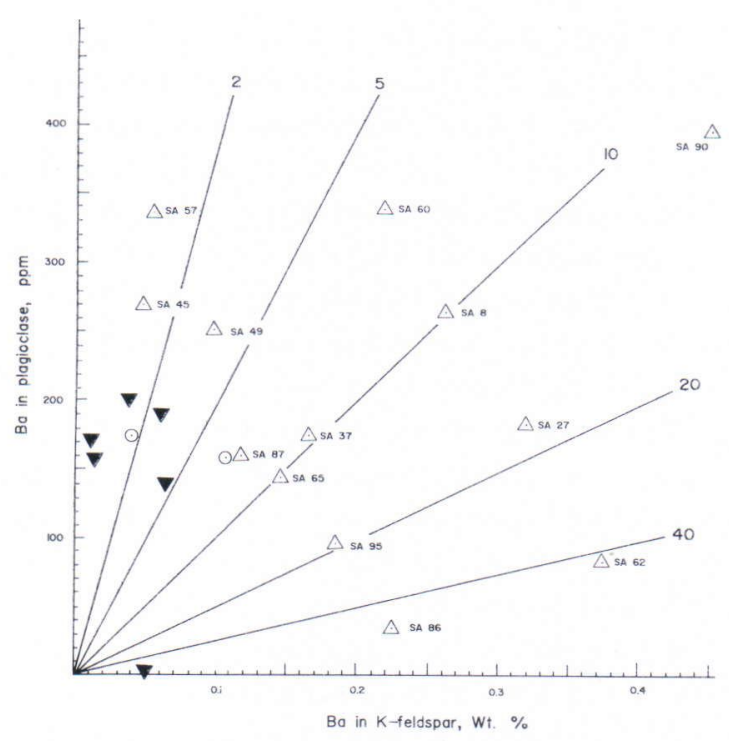

Fig. 3. Distribution of Ba between coexisting feldspars. The radiating lines give weight distribution coefficients for $\mathrm{K}$ feldspar over plagioclase. Marks as in Figs. 1 and 2.

the Bobbejaankop granite are particularly characterized by low abundances of $\mathrm{Ba}, \mathrm{Sr}$, and $\mathrm{Ti}$ and high contents of $\mathrm{Rb}$, suggesting that the Main and Bobbejaankop granites could be related through fractionation from a single parent magma. In addition, the stratiform Main granite shows a slight but consistent trend towards lower $\mathrm{K} / \mathrm{Rb}$ and $\mathrm{Ba} / \mathrm{Rb}$ ratios accompanied by a complementary increase in $\mathrm{Ba} / \mathrm{Sr}$ and $\mathrm{Ca} / \mathrm{Sr}$ ratios in the stratigraphically higher parts of the intrusion (McCarthy and Hasty 1976, McCarthy and Fripp 1980). Although the whole rock analyses of the Lease granite show the lowest $\mathrm{K} / \mathrm{Rb}, \mathrm{Ba} / \mathrm{Sr}$ and $\mathrm{Ba} / \mathrm{Rb}$ ratios of all three granite types featuring extreme fractionation, the microprobe analyses in the present study do not endorse this trend. The number of the analyses in the present study, however, is too low for firm conclusions to be drawn.

The uppermost, as well as the coarse-grained lower Main granite has the highest $\mathrm{Ba}$ and $\mathrm{Sr}$ contents, apparently as a result of the early crystallization of $\mathrm{K}$-feldspar and plagioclase, and the strong partitioning of $\mathrm{Ba}$ into the $\mathrm{K}$ feldspar and of $\mathrm{Sr}$ into both $\mathrm{K}$-feldspars and plagioclases.

The higher Ca content of the Bobbejaankop granite than that of the Main granite, as shown by whole rock analyses (Lenthall and Hunter 1977) can be ascribed to the occurrence of fluorite and calcite as common constituents in the Bobbejaankop granite.

According to the geochemical data, the initial crystallization could have started at both the top and the bottom of the Main granite intrusive. The high thermal states of the K-feldspar in the coarse-grained leuco- or mesocratic Main granite can be interpretted as a result of dry crystallization conditions (Ollila 1981, 1984 a) and may indicate a cumulate origin for the rock.

The chemistry of the Bobbejaankop and Lease granite cassiterites defines slightly different trends, although the detection limit of the electron microprobe for most elements, about 100 ppm, prevented more accurate determinations. The average niobium content $(0.13$ per cent $\left.\mathrm{Nb}_{2} \mathrm{O}_{5}\right)$ is higher, whereas the tantalum $(0.50$ per cent $\mathrm{Ta}_{2} \mathrm{O}_{5}$ ) and iron ( 0.62 per cent $\left.\mathrm{FeO}\right)$ contents are lower in the orthomagmatic cassiterites from the disseminated Bobbejaankop granite than in cassiterites from the greisenized Lease granite $\left(\mathrm{Nb}_{2} \mathrm{O}_{5} 0.30\right.$ per cent; $\mathrm{Ta}_{2} \mathrm{O}_{5} 0.11$ per cent; and $\mathrm{FeO} 0.79$ per cent). The tungsten contents are similar, 0.78 per cent $\mathrm{WO}_{3}$ in dark colour zones and 0.06 per cent in light colour zones, in all the Zaaiplaats cassiterites analysed by microprobe.

The abundant presence of highly saline fluid inclusions in both the Bobbejaankop and Lease granites (Ollila 1984 b) supports the view that the Bobbejaankop magma achieved water saturation fairly early during its crystallization (Groves and McCarthy 1978), and that the Lease granite may be a product of metasomatism and recrystallization (Ollila 1984 a). 


\section{Conclusions}

According to the present study, the average weight distribution coefficient of $\mathrm{Ba}$ for the $\mathrm{K}$ feldspars over plagioclases and the average $\mathrm{Ba}$ content of the $\mathrm{K}$-feldspars are about five times higher in the Main granite than in the tin-bearing Bobbejaankop granite. The average $\mathrm{K} / \mathrm{Ba}$ ratios of the $\mathrm{K}$-feldspars in the Main and Bobbejaankop granites are 127 and 611, respectively.

These data, with other geochemical data available from the Zaaiplaats area, support the hypothesis that these granites formed by in situ fractional crystallization of a single parent magma. It is concluded that: (i) the Bobbejaankop granite represents a residual fraction of the Main granite magma, (ii) initially tin was concentrated in silicate melt by the mechanism of fractional crystallization in the Main granite magma, (iii) the occurrence of the tin

\section{References}

De Waal, S. A., 1972. The Bushveld granites in the Zaaiplaats area. Geol. Soc. S. Afr. Trans. 76, 135-148.

Groves, D. I. \& T. S. McCarthy, 1978. Fractional crystallization and the origin of tin deposits in granitoids. Miner. Deposita 13, 11-26.

Lenthall, D. H. \& D. R. Hunter, 1977. The geochemistry of the Bushveld granites in the Potgietersrus tin-field. Precambrian Res. 5, 359-400.

McCarthy, T. S. \& R. E. P. Fripp, 1980. The crystallization history of a granitic magma, as revealed by trace element abundances. J. Geol. 88, 211-224.

McCarthy, T. S. \& R. A. Hasty, 1976. Trace element distribution patterns and their relationship to the crystallization of granitic melts. Geochim. Cosmochim. Acta 40, $1351-1358$. deposits in the roof zone of the Bobbejaankop granite implies further enrichment of tin via silicate melt during crystallization of this granite, or via aqueous fluid phase derived from the magma after initial water saturation was achieved, (iv) the Lease granite is probably a highly metasomatised recrystallization product of the Bobbejaankop granite rather than a quenched residual liquid, (v) in addition to the geochemical parameters such as $\mathrm{K} / \mathrm{Rb}, \mathrm{Ba} / \mathrm{Rb}$ and $\mathrm{Ba} / \mathrm{Sr}$ ratios in whole rock analyses, determination of $\mathrm{Ba}$ content and $\mathrm{K} / \mathrm{Ba}$ ratio in $\mathrm{K}$-feldspars is potentially useful in tin exploration carried out in an environment of multi-phase granitoid intrusions.

Acknowledgment. This paper is published with the permission of the president of MINTEK (Council for Mineral Technology, Randburg, South Africa). The author is grateful to Dr. Seppo Lahti for critical comments of the manuscript.
Ollila, J. T., 1981. A fluid inclusion and mineralogical study of tin deposits and rocks associated with the Bushveld Complex at the Zaaiplaats, Rooiberg and Union tin mines in the Central Transvaal, South Africa. Ph.D. thesis, Rand Afrikaans Univ., Johannesb., 257 p.

Ollila, J. T., 1984 a. The crystallization of a tin-bearing granitoid suite: the Bushveld granites in the Zaaiplaats area, South Africa. Bull. Geol. Soc. Finland 56, 75-88.

Ollila, J. T., 1984 b. Fluid inclusions and tin deposition at Zaaiplaats, the Central Transvaal, South Africa. Bull. Geol. Soc. Finland 56, 59-73.

Smith, J. V., 1974. Feldspar Minerals II. Chemical and textural properties. Springer-Verlag, Berlin, New York, $690 \mathrm{p}$.

Manuscript received, 12 July 1983. 